Developing Intercultural Competence in Practice 
Languages for Intercultural Communication and Education

Editors: Michael Byram, University of Durham, UK

and Alison Phipps, University of Glasgow, UK

The overall aim of this series is to publish books which will ultimately inform learning and teaching, but whose primary focus is on the analysis of intercultural relationships, whether in textual form or in people's experience. There will also be books which deal directly with pedagogy, with the relationships between language learning and cultural learning, between processes inside the classroom and beyond. They will all have in common a concern with the relationship between language and culture, and the development of intercultural communicative competence.

\section{Other Books of Interest}

Foreign Language and Culture Learning from a Dialogic Perspective Carol Morgan and Albane Cain

The Good Language Learner

N. Naiman, M. Fröhlich, H.H. Stern and A. Todesco

Language, Culture and Communication in Contemporary Europe Charlotte Hoffman (ed.)

Language Learners as Ethnographers

Celia Roberts, Michael Byram, Ana Barro, Shirley Jordan and Brian Street

Language Teachers, Politics and Cultures Michael Byram and Karen Risager

Motivating Language Learners Gary N. Chambers

New Perspectives on Teaching and Learning Modern Languages Simon Green (ed.)

Teaching and Assessing Intercultural Communicative Competence Michael Byram

Please contact us for the latest book information:

Multilingual Matters, Frankfurt Lodge, Clevedon Hall,

Victoria Road, Clevedon, BS21 7HH, England

http://www.multilingual-matters.com 


\section{Developing Intercultural Competence in Practice}

Edited by

Michael Byram, Adam Nichols

and David Stevens

MULTILINGUAL MATTERS LTD

Clevedon • Buffalo • Toronto $\bullet$ Sydney 
Library of Congress Cataloging in Publication Data

Developing Intercultural Competence in Practice/Edited by Michael Byram, Adam

Nichols and David Stevens

Includes bibliographical references and index.

1. Intercultural communication-Study and teaching. 2. Multicultural education.

3. Language and languages-Study and teaching. I. Byram, Michael.

II. Nichols, Adam, III. Stevens, David

P94.6.D48 2001

370.117-dc21 2001030233

British Library Cataloguing in Publication Data

A catalogue entry for this book is available from the British Library.

ISBN 1-85359-537-3 (hbk)

ISBN 1-85359-536-5 (pbk)

Multilingual Matters Ltd

UK: Frankfurt Lodge, Clevedon Hall, Victoria Road, Clevedon BS21 7HH.

USA: UTP, 2250 Military Road, Tonawanda, NY 14150, USA.

Canada: UTP, 5201 Dufferin Street, North York, Ontario M3H 5T8, Canada.

Australia: Footprint Books, Unit 4/92a Mona Vale Road, Mona Vale, NSW 2103, Australia.

Copyright (c) 2001 Michael Byram, Adam Nichols, David Stevens and the authors of individual chapters.

All rights reserved. No part of this work may be reproduced in any form or by any means without permission in writing from the publisher.

Typeset by Exe Valley Dataset Ltd, Exeter, England.

Printed and bound in Great Britain by the Cromwell Press Ltd. 